\title{
The Effect of U-Dictionary on Vowel Pronunciation Ability of the Tenth Grade Students
}

\author{
Krismonika $^{1 *}$, Maida Norahmi ${ }^{2}$, Natalina $\mathrm{Asi}^{3}$ \\ 1,2, 3 The Study Program of English Education, Faculty of Teacher Training and Education \\ University of Palangka Raya
}

\begin{abstract}
The objective of this research was to find out the empirical data which could determine whether there is a significance of using U-Dictionary application on vowel pronunciation ability of the tenth-grade students of SMA Kristen Palangka Raya or not. The method used quantitative with pre-experimental research method with One Group Pretest-Posttest Design. The samples of this research were 30 students of the tenth grade. The samples were selected by total sampling. To collect the data, this research used a pronunciation test which had been tried out provided in pretest and posttest as the research instrument. The result of this research revealed that the mean score of the posttest was greater than that of the pretest, namely $66.33>49.17$. Then the result of hypotheses testing showed that the critical value for the one-tailed test is ta with $\mathrm{df}=\mathrm{n}-1,30-1=29$. The value of the test statistic, is $t^{*}=-6.809$ and the critical value of $t 0$ is $t .05\{29\}=-1.699$. Because $t^{*}<t .05$ $\{29\}=-6.809<-1.699$, we reject $\mathrm{H} 0$. The test results were statically significant at the $5 \%$ level. It means that there is a significant effect of using the U-Dictionary application on the vowel pronunciation ability of the students of SMA Kristen Palangka Raya.
\end{abstract}

Keywords: pronunciation ability, U-Dictionary, vowel

\section{INTRODUCTION}

Pronunciation is an important aspect to master in communicating appropriately and fluently. The importance of attention to pronunciation since it can direct someone's message to be passed or not by another people. Pronunciation significantly affect the meaning of someone's utterances. English pronunciation is one of the difficult skills to master by students, for example when students pronounce the word "laugh" but sometimes they pronounce it like "love". This difficulty comes from the different sounds produced by the written spelling. In English, there are many words share similar spellings, they are sometimes pronounced differently because of their surrounding contexts like tenses and phonemes constructing the words. This differences could potentially cause a lot of problems for non-native speakers of English and create another confusion in producing the English words (Leong \& Ahmadi, 2017). This is why teaching pronunciation should be taken into more consideration in English learning in the classroom.

People should have good pronunciation to understand each other and to achieve the goals to be intelligible speaker. According to Gilakjani (2016), the objective of teaching pronunciation is not to force the students to build perfect pronunciation to become more native-like. Achieving correct pronunciation is aimed at the first place and should support the meaningful communication. It is also not prohibited if the students want to change their

\footnotetext{
*Corresponding author: krismonika007@gmail.com

To cite this article: Krismonika, Norahmi, M., \& Asi, N. (2021). The Effect of U-Dictionary on Vowel Pronunciation Ability of the Tenth Grade Students. Ebony --- Journal of English Language Teaching, Linguistics, and Literature, 1 (1) 2021, pp. 22--33.
} 
way of pronouncing English words, but it will be harder for them to change their way to know more about the sounds of those words. Once, it can take longer time to really master the sounds that are absent in their mother tongue. Then, the focus is slightly undirected since the purpose is the meaningful communication not the perfect pronunciation. The correct perception should be that good pronunciation will carry on information clearly to estimate speaking skills that need to consolidate, and it doesn't mean it has to be perfect and nativelike. Moreover, it is expected not only to focus exclusively on the information that we want to relay, but people understand what we want really to say.

In the use of English, in Indonesia, English is still viewed as a foreign language (EFL) since it is not used as formal, business, and academic medium of communication. Most activities in those sectors mainly rely on national language and mother tongue. Then, English is still rarely used in daily life and has less chance to be practiced by the language learners. The same situation happened in Palangka Raya, as one of the provinces in Indonesia, and English is also taught in formal school, but the exposure of using English as EFL is very limited. As the subject of this research, in SMA Kristen Palangka Raya, English is taught in each semester, wherein each semester, students learn about English language material related to speaking skills in English, and in these speaking skills, there is an aspect of pronunciation in English which they will learn indirectly to find out the correct way of speaking in English words. Students are taught harder in speaking tests by themselves and some students could not achieve high scores or just average scores on their assignments and examinations. It was found that some students had difficulty in how to distinguish sounds and lack of information about learning sounds in English pronunciation.

Harmer (2009) and Gilakjani (2012) stated that pronunciation teaching not only makes students aware of a different sound to sound feature but can also improve their speaking immeasurably, so the learners can understand each other when the sounds try to produce. In teaching pronunciation, factors such as age at the acquisition of a language, the learner's motivation for learning the language and the culture group that the learner identifies and spends time with determining whether the learner will develop native-like pronunciation. In terms of speaking, teachers should also concern about the micro-skills; there are grammar, vocabulary, pronunciation, and spelling. The aspect of pronunciation that can be taught does not consist only of the segmental features like how to pronounce vowel and consonant therefore also the supra-segmental features such as rhythm and intonation (Dalton \& Seidlhofer, 2001). The teachers need to realize how important pronunciation is. Students who cannot pronounce well cannot express what they intend to and may lose their confidence too. Realizing the importance of pronunciation, teachers should be able to convince students. So that they have the willingness to improve their English pronunciation.

The vowel is a speech sound that is produced by the configuration of the vocal tract that is relatively open, with the vibration of vocal cords but without audible friction, and which is a unit of the sound system that forms the core of a syllable. This vowel sound is a part of learning English pronunciation and also a part that is difficult and important because in pronunciation we will often listen to words that have a vowel sound and because most people who are just learning a foreign language especially Indonesian people often make mistakes in pronouncing vowel sounds and the difficulty of distinguishing sounds from one 
sound to another sound like I sound and i: sound. In learning the pronunciation of a vowel, students must understand and be able to distinguish sounds, because when the students pronounce it wrongly, it can change the meaning of the word (Singleton, 2016). For example, it /It/ and eat /i:t/, how to pronounce them is almost the same but it has different vowel sound and meaning. The other example is like how to pronounce love $/ \mathrm{l} \Lambda \mathrm{v} /$ and laugh $/$ læf/ because how to pronounce them is almost the same but it has different vowel sound and meaning.

Technological tools have been regarded as ways of helping students improve language skills such as pronunciation. Much Technology like applications can improve our skills, the example of technology is the U-Dictionary application made by NetEase (a Chinese Internet technology company). U-Dictionary is an offline application and has many languages like (English, Indonesian, Italian, Javanese, and other languages) this dictionary can check our pronunciation with transcript and authentic UK (British) and US (American) accent. In this application, there is a transcript from Oxford Dictionary, there is also a conversation icon that is very suitable for practicing speaking skills and how to pronounce vowel sound correctly, it also has a speaker icon that can listen to native speaker sounds and also has simple sentences which we can try to challenge ourselves and this application has uses in practicing pronunciation and is easy to use. In accordance to this matter, electronic dictionaries save their secured place within the process of pronunciation learning among the EFL learners. Zheng \& Wang (2016) and Metruk (2017) found that the EFL learners used their technological devices to assist them in learning, especially downloading electronic dictionaries and consult pronunciation fairly often during the learning.

The EFL learners can use this application on any android phone because the application size is not large, can be used anywhere, anytime, and with anyone. U-Dictionary can help students in learning how to pronounce English well and correct pronunciation, students can challenge themselves in learning the pronunciation in English so that students can find out the value of pronunciation points they will get. U-Dictionary can be used in formal situations (at school) as a teacher's teaching tool to find out the extent of students' abilities in their pronunciation and can also be used in informal situations (at home) as selftaught learning tools for students in developing their pronunciation ability. By considering those advantages offered by this application, an experimental research was conducted to investigate whether it could help improve the pronunciation ability of the tenth-graders in SMA Kristen Palangka Raya.

\section{METHODS}

This research applied a pre-experimental research method with "One Group Pre-test and Post-test Design", where it only consisted of one group. This research would try to examine in one group to make it easier and more focused. The treatment was to teach how to pronounce vowel sounds, then present research would try to examine in one group to make it easier and more focused. During the implementation of the treatment, the researcher would give a pretest without the media to saw the students' ability on vowel pronunciation. The treatment was given to the students in three meetings by using U-Dictionary as a learning medium to help the students compare and consult their pronunciation independently. The 
posttest was the final test given in the last meeting to see the effect of whether the use of Udictionary was significantly influenced the pronunciation ability.

The research used all tenth-grade students at SMA Kristen Palangka Raya as the research samples. The students were given a pretest in the first meeting, then they were given the treatment using the U-Dictionary application for three meetings during the classes. A posttest was finally administered in the last meeting. In this research, the researcher used a pronunciation test which was the list of vocabulary on vowel sounds as the research instrument. The students' responses to the test were recorded using an electronic voice recorder on smartphone as the data to be analyzed.

The research determined the normality of each data pretest and posttest. The normality test was conducted using Liliefors to find out whether the data conformed to a normal distribution or non-normal distribution, if the data shows a normal distribution, then this research would use the formula of dependent-sample T-test.

$$
t^{*}=\frac{\sum D}{\frac{\sqrt{n \sum D-\left(\sum D\right)^{2}}}{n-1}}
$$

Where:

$\mathrm{t}=$ The obtained $\mathrm{t}$ value

$\mathrm{D}=$ The difference between a pair of scores

$\mathrm{n}=$ Number of pairs

But if the data shows to a non-normal distribution, the researcher would use formula of Wilcoxon matched pairs signed-rank test.

$$
Z^{*}=\frac{w *-\frac{n(n+1)}{4}}{\frac{\sqrt{n(n+1)(2 n+1)}}{24}}
$$

Where:

$\mathrm{W}=$ Wilcoxon matched-pairs signed-ranks test statistic

$\mathrm{N}=$ The number of subject who has a difference score between first test and second test beside 0 (zero point)

The hypotheses of the research are as follows:

Ho: U-Dictionary on has no effect toward students 'English on vowel pronunciation at the tenth grade SMA Kristen Palangka Raya $($ Ho $: \mu 1=\mu 2)$.

Ha: U-Dictionary has significant effect toward students' English on vowel pronunciation at the tenth grade SMA Kristen Palangka Raya $(\mathrm{Ha}: \mu 1<\mu 2)$ 
Table 1. Pretest Instrument

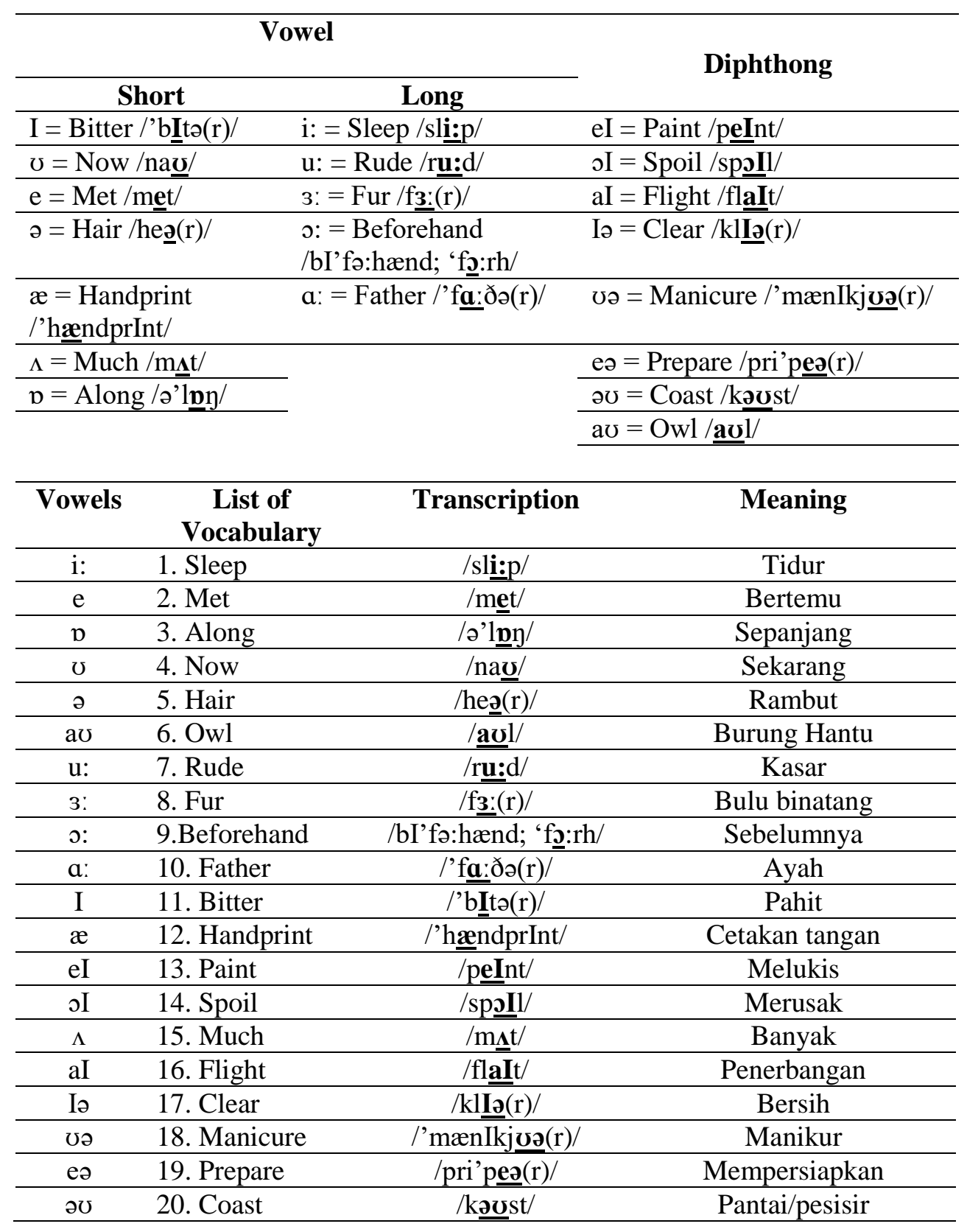

The pretest and posttest instrument has the same type of the task, namely the list of vocabulary to be spoken, that consisted of vowel sounds. However, this instrument has a difference in the content. As part of the list of vocabulary by providing a different content, students could recognize the words to get more vocabulary in English and can know how to pronounce them correctly. This instrument was equipped with a distinguishing table between long, short, and diphthong as well as a vowel table, list of vocabulary table, transcription table, and meaning table. 
Table 2. Posttest Instrument

\begin{tabular}{|c|c|c|c|}
\hline \multicolumn{3}{|c|}{ Vowel } & \multirow{2}{*}{ Diphthong } \\
\hline \multicolumn{2}{|c|}{ Short } & Long & \\
\hline \multicolumn{2}{|c|}{$\mathrm{I}=$ Betray $/ \mathrm{b} \underline{\mathbf{I}}$ 'tre $\underline{\mathbf{I}} /$} & $\mathrm{ed} / \mathrm{fi}: \mathrm{d} /$ & eI = Sale /seIll \\
\hline \multicolumn{2}{|c|}{$\mho=$ About $/ \underline{\underline{\mathbf{g}}}$ bavt $/$} & rew /stru:/ & oI = Avoid /ə’voId/ \\
\hline \multicolumn{2}{|c|}{$\mathrm{e}=\mathrm{Net} / \mathrm{ne} / \mathrm{t}$} & orld /w3:ld; & $\mathrm{aI}=$ Height /haIt/ \\
\hline \multicolumn{2}{|c|}{$\boldsymbol{\partial}=$ Fear /fi(文)r/ } & $\begin{array}{l}\text { atermelon } \\
\text { melən/ }\end{array}$ & $\mathrm{I} ə=$ Near $/ \mathrm{n} \underline{\mathbf{I}} \underline{(\mathrm{r})} /$ \\
\hline \multicolumn{2}{|c|}{$\mathfrak{x}=$ Animal $/ \underline{\mathfrak{a} n I m ə l} /$} & ard /ha:d; & 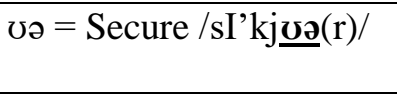 \\
\hline \multirow{2}{*}{\multicolumn{2}{|c|}{$\begin{array}{l}\Lambda=\text { Under /' } \underline{\underline{\Lambda}} \mathrm{ndə}(\mathrm{r}) / \\
\mathrm{a}=\text { Horrible /'harabl/ }\end{array}$}} & & eə = Square /skwe $\underline{\text { ê }}(\mathrm{r}) /$ \\
\hline & & & $\partial \mho=$ Propose /pro'powz;/ \\
\hline \multicolumn{3}{|c|}{ 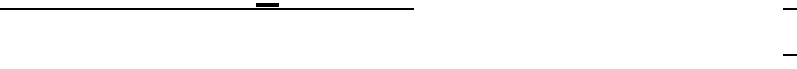 } & $\mathrm{a} v=$ Out $/ \underline{\underline{\mathbf{a v}}} \underline{\underline{t}} / /$ \\
\hline Vowels & $\begin{array}{c}\text { List of } \\
\text { Vocabulary }\end{array}$ & Transcription & Meaning \\
\hline I & 1. Betray & /bI'treI/ & Mengkhianati \\
\hline$\partial$ & 2. Fear & /fi(o)r/ & Takut \\
\hline$æ$ & 3. Animal & /ânIməl// & Binatang/hewan \\
\hline$\Lambda$ & 4. Under & /'يndə(r)/ & Di bawah \\
\hline U & 5. About & /a’bavt/ & Tentang \\
\hline$a$ & 6. Horrible & /'harəbl/ & Mengerikan \\
\hline$\partial U$ & 7. Propose & /pro'pozz;; & Mengusulkan \\
\hline i: & 8. Feed & /fi: $/ \mathrm{d} /$ & Makanan \\
\hline $\mathrm{u}:$ & 9. Strew & /stru:/ & Menabur \\
\hline 3: & 10. World & /w3:1d; w3:rld/ & Dunia \\
\hline o: & 11. Watermelon & /'wo:təmelən/ & Semangka \\
\hline$a:$ & 12. Hard & /ha:d; ha:rd/ & Sulit \\
\hline eI & 13. Sale & /s $\underline{\text { eIl/ }}$ & Jual \\
\hline oI & 14. Avoid & 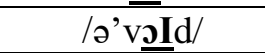 & Menghindari \\
\hline aI & 15. Height & /hät/ & Tinggi \\
\hline Iə & 16. Near & /nI主(r)/ & Dekat \\
\hline ขə & 17. Secure & /sI'kjō(r)/ & Aman \\
\hline eə & 18. Square & /skwę(r)/ & Persegi (shape) \\
\hline $\mathrm{e}$ & 19. Net & /net/ & Jaring \\
\hline av & 20. Out & /avt/ & Keluar \\
\hline
\end{tabular}

\section{RESULTS}

The objective of this research was to find out the effect of U-Dictionary on vowel pronunciation ability of the tenth-grade students of SMA Kristen Palangka Raya. This research was to see if there was a significant effect on students of X MIPA that obtained the treatment of using U-Dictionary application on vowel pronunciation ability in the classroom, the data needed in this research were the students' vowel pronunciation scores, the scores resulted from pretest and posttest performed by the tenth-grade students of SMA Kristen Palangka Raya in the academic year 2020.

The pretest was conducted and 15 students participated. The researcher asked the students to pronounce the 20 vowel sound from the table that the researcher gave for the 
pretest. The researcher asked the students to pronounce the list of vocabulary tables with a focus on the transcription table. Then the voice of the students was recorded one by one by themselves, after finishing the recording, the voices were analyzed. The data are presented as follows:

Table 3. Data of Students' Pronunciation Score (Pretest)

\begin{tabular}{lcccc}
\hline No & $\begin{array}{c}\text { Student' } \\
\text { code }\end{array}$ & \multicolumn{2}{c}{ Students' Pronunciation } & \multirow{2}{*}{ Final Score } \\
\cline { 3 - 4 } & & Correct & Incorrect & \\
\hline 1. & S-1 & 14 & 6 & 70 \\
\hline 2. & S-2 & 7 & 13 & 35 \\
\hline 3. & S-3 & 4 & 16 & 20 \\
\hline 4. & S-4 & 10 & 10 & 50 \\
\hline 5. & S-5 & 13 & 7 & 65 \\
\hline 6. & S-6 & 12 & 8 & 60 \\
\hline 7. & S-7 & 13 & 7 & 65 \\
\hline 8. & S-8 & 12 & 8 & 60 \\
\hline 9. & S-9 & 7 & 13 & 35 \\
\hline 10. & S-10 & 10 & 10 & 50 \\
\hline 11. & S-11 & 8 & 12 & 40 \\
\hline 12. & S-12 & 3 & 17 & 15 \\
\hline 13. & S-13 & 12 & 8 & 60 \\
\hline 14. & S-14 & 9 & 11 & 45 \\
\hline 15. & S-15 & 4 & 16 & 20 \\
\hline Total Score & & & 690 \\
\hline Mean & & & & 46.00 \\
\hline
\end{tabular}

In Table 3, it can be seen that the mean $(\overline{\mathrm{x}})$ of the students' score is 46.00 with a standard deviation of 17.948. The researcher concluded that the students were not familiar enough with vowel pronunciation of the words presented in this research. It was found that there were 14 students got score under 70, 1 student who got 15, 2 students who got 20, 2 students who got 35,1 student who got 40, 1 student who got 45, 2 students who got 50, 3 students who got 60, 2 students who got 65 and 1 student who got 70, it means the scores of the pretest was lower and not achieve the completeness of criteria, because the determination of completeness criteria is 70 in SMA Kristen Palangka Raya.

Before the researcher gave a posttest, the researcher gave students the treatment using U-Dictionary for three meetings. The researcher gave a posttest to the students and 15 students participated. The procedure of the posttest was the same as the pretest, the researcher asked the students to pronounce the 20 vowel sound from the table that the researcher gave for the pretest. The researcher asked the students to pronounce the list of vocabulary tables using U-Dictionary and with a focus on transcription in the application. Then the voice of the students was recorded one by one by themselves, after finishing the recording, the voices were analyzed, the data are presented as follows: 
Table 4. Data of Students' Pronunciation Score (Posttest)

\begin{tabular}{lcccc}
\hline No & $\begin{array}{c}\text { Student' } \\
\text { code }\end{array}$ & \multicolumn{2}{c}{ Students' Pronunciation } & \multirow{2}{*}{ Final Score } \\
\cline { 3 - 4 } & & Correct & Incorrect & \\
\hline 1. & S-1 & 16 & 4 & 80 \\
\hline 2. & S-2 & 15 & 5 & 75 \\
\hline 3. & S-3 & 14 & 6 & 70 \\
\hline 4. & S-4 & 14 & 6 & 70 \\
\hline 5. & S-5 & 16 & 4 & 80 \\
\hline 6. & S-6 & 12 & 8 & 60 \\
\hline 7. & S-7 & 16 & 4 & 80 \\
\hline 8. & S-8 & 17 & 3 & 85 \\
\hline 9. & S-9 & 8 & 12 & 40 \\
\hline 10. & S-10 & 18 & 2 & 90 \\
\hline 11. & S-11 & 13 & 7 & 65 \\
\hline 12. & S-12 & 9 & 11 & 45 \\
\hline 13. & S-13 & 11 & 9 & 55 \\
\hline 14. & S-14 & 12 & 8 & 60 \\
\hline 15. & S-15 & 9 & 11 & 45 \\
\hline \multicolumn{2}{l}{ Total Score } & & & 1.000 \\
\hline Mean & & & & 66.67 \\
\hline
\end{tabular}

Table 4 showed that the mean $(\overline{\mathrm{x}})$ of the students' score is 66.67 with a standard deviation of 15.546. It was found that 7 students got a score under 70, 2 students got 70, 1 student got 75, 3 students got 80, 1 student got 85, and 1 student got 90 . It means after the treatment of using the U-Dictionary application the students' scores on the posttest increased and achieve the completeness criteria.

After the normality test the result was obtained, the researcher decided to use formula of dependent t-test as follow:

$$
t^{*}=\frac{\sum D}{\frac{\sqrt{n \sum D-\left(\sum D\right)^{2}}}{n-1}}
$$

Where:

$$
\begin{aligned}
& t=\text { The obtained } t \text { value } \\
& D=\text { The difference between a pair of scores } \\
& n=\text { Number of pairs }
\end{aligned}
$$

The calculation is summarized in table 5 as follow:

Table 5. The Statistic of Formula Dependent Sample t-Test

\begin{tabular}{ccccc}
\hline Subject & $\begin{array}{c}\text { Score } \\
\text { X1 }\end{array}$ & $\begin{array}{c}\text { Score } \\
\mathbf{X 2}\end{array}$ & $\begin{array}{c}\text { Difference } \\
(\mathbf{X 1}-\mathbf{X 2}) \mathbf{D}\end{array}$ & $\begin{array}{c}\text { (Difference) }^{\mathbf{2}} \\
(\mathbf{X 1}-\mathbf{X 2})^{\mathbf{2}} \mathbf{D}^{\mathbf{2}}\end{array}$ \\
\hline S1 & 70 & 80 & -10 & 100 \\
\hline S2 & 35 & 75 & -40 & 1600 \\
\hline S3 & 20 & 70 & -50 & 2500 \\
\hline S4 & 50 & 70 & -20 & 400 \\
\hline S5 & 65 & 80 & -15 & 225 \\
\hline
\end{tabular}




\begin{tabular}{ccccc}
\hline S6 & 60 & 60 & 0 & 0 \\
\hline S7 & 65 & 80 & -15 & 225 \\
\hline S8 & 60 & 85 & -25 & 625 \\
\hline S9 & 35 & 40 & -5 & 25 \\
\hline S10 & 50 & 90 & -40 & 1600 \\
\hline S11 & 40 & 65 & -25 & 625 \\
\hline S12 & 15 & 45 & -30 & 900 \\
\hline S13 & 60 & 55 & 5 & 25 \\
\hline S14 & 45 & 60 & -15 & 225 \\
\hline S15 & 20 & 45 & -25 & 625 \\
\hline $\mathbf{N = 1 5}$ & & & $\mathbf{\Sigma D}=\mathbf{- 3 1 0}$ & $\mathbf{\Sigma} \mathbf{D}^{2}=\mathbf{9 7 0 0}$ \\
\hline
\end{tabular}

Based on the data, we had $\Sigma \mathrm{D}=-310$ and $\Sigma \mathrm{D}^{2}=9700$. Plugging those values into the formula of the T-test for two dependent samples, we obtain a t value:

$$
\begin{aligned}
t^{*} & =\frac{\sum D}{\frac{\sqrt{n \sum D-\left(\sum D\right)^{2}}}{n-1}} \\
\mathrm{t}^{*} & =\frac{-310}{\sqrt{\frac{15(9700)-(-310)^{2}}{15-1}}} \\
& =\frac{-310}{\sqrt{\frac{145,500-96,100}{14}}} \\
& =\frac{-310}{\sqrt{3528.57143}} \\
\mathrm{t}^{*} & =\frac{-310}{59.4017797}=-5.218
\end{aligned}
$$

The critical value for a one-tailed test is $\mathrm{t}_{\alpha}$ with $\mathrm{df}=\mathrm{n}-1,15-1=14$. In table $\mathrm{C}$ in appendix, namely table of Critical Values for $\mathrm{t}$ Distribution, showed that for $\mathrm{df}=14, \mathrm{t} .05\{14\}=-1.761$. The value of the test statistic, is $t^{*}=-5.218$ and the critical value of $t_{0}$ is $t_{.05}\{14\}=-1.761$. Because $\mathrm{t}^{*}<\mathrm{t}_{.05}\{14\}=-5.218<-1.761$, we reject $\mathrm{H}_{0}$. The test results were statically significant at the $5 \%$ level. It means that hypothesis which stated that there was a significant difference of using U-Dictionary on vowel pronunciation ability of the tenth-grade students of SMA Kristen Palangka Raya was accepted.

\section{DISCUSSION}

From this research, it was found that of the 15 students studied, there was 1 student who had decreased and did not reach the standard of assessment at SMA Kristen Palangka Raya. Two causes can be related to the problems experienced by a student, namely: First, lack of motivation, which is because the student was possibly afraid of making mistakes in trying to pronounce English words, and second cause, the influence of their native language, which is accustomed to using the Dayak Ngaju language used to communicate with the surrounding environment, as well as the influence of the accent and is usually carried away when the 
student trying to pronounce the English language. Similar to Gerald (2000) and Jones (2000) finds out few difficulties regarding pronunciation that tudents have to make foreign sounds with their organs of speech. In learning English pronunciation there might be some aspects that make the learner of a foreign language make an error. The effect is not only because English is not their native language but also because of some factors like age, amount and type of prior pronunciation instruction, aptitude, motivation, and native language.

According to the result about the use of U-Dictionary application in the English learning process, the researcher concluded that the U-Dictionary had some strengths and weaknesses. As stated in chapter II, the strengths were the use of U-Dictionary: it has a transcript from oxford dictionary; it can be used in an offline situation; has a good pronunciation, because there are two types of accents, there are UK (British) and US (American); there is a simple sentence to challenge yourself in pronunciation; it has a sound icon that can listen to the sound from native speakers about good pronunciation and has a conversation icon that can be translated directly; there is a game that can hone pronunciation like spelling games and this application could help students in developing ideas for pronunciation ability. And the weaknesses of U-Dictionary were; this application does not have vowel charts, it does not has pictures of organs of speech, and also too many ads appearing in this application.

During the treatment, some students were active and interested in the learning process, similar to the previous research done Alfallaj (2013) indicates that an electronic dictionary is one of the media which helps students with pronunciation as nearly $60 \%$ of the subjects claimed that they use electronic dictionaries also for pronunciation. In addition According to Kent (2001), half of the respondents in his study claimed that audio pronunciation was the most useful feature of electronic dictionaries. And according to Dwaik (2015), only $20 \%$ of students use the electronic dictionaries in the context of speaking (pronunciation being an inseparable part of the speaking skills), which might seem fairly strange as it was a pronunciation that posed problems for the subjects who participated in the study, and electronic dictionaries would prove helpful in this respect. The students get their independent learning in checking their electronic dictionaries to get the real exposures of pronouncing the words (Dashtestani, 2015; Alhaisoni, 2016). From the result obtained, it is also confirmed that the online dictionaries has its own merits in helping the students learn pronunciation as it provides big data, updated convenient features, and the ease at accessibility.

The use of U-Dictionary as a media also made the scores of the students in the classroom increased after the treatment. When the researcher analyzed the score of pretest and posttest using Liliefors test it was found that pretest and posttest conform to a normal distribution. And also the posttest conforms to a normal distribution, for this reason, the researcher would use a formula of dependent T-test. Base on the data, we had $\Sigma \mathrm{D}=-310$ and $\Sigma \mathrm{D} 2=9700$. Plugging those values into the formula of the T-test for two dependent samples, the value of the test statistic, is $t^{*}=-5.218$ and the critical value of $t 0$ is $t .05\{14\}=-1.761$. Because $t^{*}<\mathrm{t} .05\{14\}=-5.218<-1.761$, we reject $\mathrm{H} 0$. The test results were statically significant at the $5 \%$ level. 


\section{CONCLUSION}

This research concludes that most of the tenth-grade students of SMA Kristen Palangka Raya experienced significant improvement in learning English vowel pronunciation using UDictionary application and only a few number of the students who did not experience improvement when using this application. However, likely, the students who do not experience improvement in learning vowel pronunciation can be improved, but they need more time to learn and practice if the student assist their pronunciation learning by using the U-Dictionary application. Therefore, using U-dictionary as technological and learning media can be one of the alternatives to teach and improve students' pronunciation skills on English vowels. The use of U-Dictionary as a tool to learn pronunciation is highly recommended for the teachers and students because it has simple yet complete features, user-friendly access, and good comprehensibility. It is not only used in the classroom to assist the teaching and learning process, students can practice their pronunciation using U-Dictionary application everywhere and every time. This application is considered very useful to develop both students' pronunciation skills and also autonomy learning gradually.

\section{REFERENCES}

Alfallaj, F. (2013). The use of linguistics in teaching pronunciation to Saudi students. SUST Journal of Humanities, 14(2), p. 134-143.

Alhaisoni, E. (2016). EFL teachers' and students' perceptions of dictionary use and preferences. International Journal of Linguistics, 8(6), p. 31-52

Dalton, C. \& Seidlhofer, B. (2001). Language Teaching Pronunciation Book. New York: Oxford Press University.

Dashtestani, R. (2015). EFL teachers' and students' perspectives on the use of electronic dictionaries for learning English. Computer Assisted Language Learning Electronic Journal, 14(2), p. 51-65

Dwaik, R. (2015). English digital dictionaries as valuable blended learning tools for Palestinian college students. English Language Teaching, 8(11), p. 1-10.

Gerald, K. (2000). How to Teach Pronunciation. England: Pearson Education Limited.

Gilakjani, A.P. (2012). A study of factors affecting EFL learners' English pronunciation learning and the strategies for instruction. International Journal of Humanities and Social Science, 2(3), p. 119-123.

Gilakjani, A.P. (2016). English pronunciation instruction: A literature review. International Journal of Research in English Education, 1(1), p. 1-6

Harmer, J. (2009). The Practice of English Language Teaching. New York: Longman Publishing.

Jones, D. (2000). English Pronunciation Dictionary. New York: Cambridge University.

Kent, D. (2001). Korean university freshmen's' dictionary use and perceptions regarding dictionaries. The Korea TESOL Journal, 4(1), p. 73-92. 
Leong, L.M. \& Ahmadi, S.M. (2017). An analysis of factors influencing learners' English speaking skill. International Journal of Research in English Education, 2(1), p. 3441.

Metruk, R. (2017). The use of electronic dictionaries for pronunciation practice by university EFL students. Teaching English with Technology Journal, 17(4), p. 38-51.

Singleton, D. (2016). Language and the Lexicon. An Introduction. New York: Routledge.

Zheng, H., \& Wang, X. (2016). The use of electronic dictionaries in EFL classroom. Studies in English Language Teaching, 4(1), p. 144-456. 